\title{
Use of Plastic as Partial Replacement of Fine Aggregate in Fibre Reinforced Concrete
}

\author{
Kshiteesh Gaur ${ }^{1}$, Jyotsana ${ }^{2}$, Anil Kumar Arya ${ }^{3}$, Neelesh Kumar Singh ${ }^{4}$ \\ ${ }^{1,2,3}$ (UG Student, Civil Engg. Department, SRMGPC, Lucknow, Uttar Pradesh, India) \\ ${ }^{4}$ (Assistant Professor, Civil Engg. Department, SRMGPC, Lucknow, Uttar Pradesh, India)
}

\begin{abstract}
Modern activities in India leads to use of plastic bags in excess. Plastic being non-biodegradable material, it takes years to decompose. Plastic bags have main constituent as poly-ethylene. The poly-ethylene when combusted produces a by-product of Carbon dioxide which leads to global warming.In this,we study the efficiency of reusing plastic waste in concrete by comparing compressive strength of concrete whose fine aggregate is partially replaced by plastic $(5 \%, 10 \%, 15 \%, 25 \%)$ with control concrete of M20 grade. To compensate for the strength lost due to replacement, iron fibres of diameter 1-2 mm are used in fixed amount.
\end{abstract}

Keywords: Plastic waste, Iron fibres, strength, cement, concrete(M20)

\section{Introduction}

Use of waste material in civil engineering has a huge scope as there are many means of fulfilling the quality standards lost due to waste usage. Using waste material reduces the load on environment as well as reduces cost of production.

Plastic waste's effect can be reduced by reusing it in other sectors (Hassani et al. 2005). Rebeiz's work shows that recycled PET resins can be used for precast concrete (Rebeiz 2007). Choi et al. examined the effect of PET bottles as aggregate on strength of the concrete. The result showed the reduction in weight of concrete by $6 \%$ and compressive strength reduction of about 33\%. Batayneh et al. showed that as the plastic content is increased the compressive strength of concrete is decreased (Batayneh et al. 2007). There is an improve in energy absorption capacity of fibre reinforced concrete during fracture (Banthia and Trottier 1995).

So, fine aggregate of concrete is partially replaced in various percentages $(5 \%, 10 \%, 15 \%, 20 \%$ and $25 \%)$ along with the use of iron fibres in constant quantity $\left(100 \mathrm{gm}\right.$ in 1 test cube i.e., $\left.(0.15 \mathrm{~m})^{3}\right)$.

\section{Material Used}

1. OPC:Ordinary Portland cement of grade 43 was used in concrete. OP cement does not contain any pozzolanic material.

2. Fine aggregate: Zone III fine aggregate was used locally available. It was sieved through $2.36 \mathrm{~mm}$ IS sieve.

3. Coarse aggregate: It is broken granite rocks of size $10 \mathrm{~mm}$ and $20 \mathrm{~mm}$ which were used.

4. Plastic: Thermoplastic was used. Plastic is converted to the size of fine aggregate by heat treatment and then cooling and crushing it. The plastic used in this research was bought from CIPET (Central Institute of Plastic Engineering and Technology), Lucknow.

5. Iron Scrap: Iron wires of dia $1-2 \mathrm{~mm}$ and length $5 \mathrm{~cm}$ were used in concrete as fibre reinforcement.

6. Water: Normal tap water was used.

\section{Methodology}

Following is the method adopted to prepare test specimen: -

1. First, we collect the materials required as explained earlier.

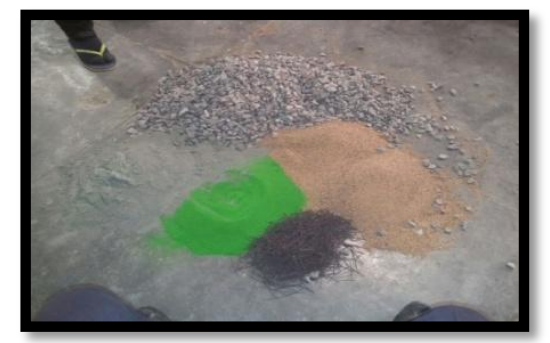

Figure 1: Materials used 
2. Testing on materials is performed to check their quality.

3. Mix design of concrete is done. M20 grade of concrete has proportion 1:1.5:3 (cement : fine aggregate : coarse aggregate) .

Taking shrinkage factor as $1.57,8$ bags of cement, $0.43 \mathrm{~m}^{3}$ of fine aggregate and $0.86 \mathrm{~m}^{3}$ of coarse aggregate is required for $1 \mathrm{~m}^{3}$ of concrete.

Now, fine aggregate is replaced in different percentages $(0,5,10,15,20,25)$. For example if $15 \%$ replacement specimen is to be made then fine aggregate content in the mix will be $0.0645 \mathrm{~m}^{3}$ of plastic and $0.3655 \mathrm{~m}^{3}$ of fine aggregate for $1 \mathrm{~m}^{3}$ of concrete (along with $100 \mathrm{gm}$ of iron fibres in 1 test cube) (rest of the materials remaining same).

4. 9 cubes are casted for every percentage of replacement. The dimension of test cube is $0.15 \mathrm{~m} \times 0.15 \mathrm{~m} \times$ $0.15 \mathrm{~m}$. According to the volume of material required for 9 cubes, materials are gathered and are mixed to prepare the concrete.

5. The prepared concrete is then casted in the form of test cubes. The cube while being filled is tamped by tamping rod to reduce the number of voids in concrete.

6. The cube is left for 1 day to gain shape.

7. Then after 24 hours of casting, the concrete cubes are obtained from the mould of test cubes. These are then left for curing.

8. Then, these cubes are tested for compressive strength on 7, 14 and 28 days from casting.

9. The test result obtained is then analyzed.
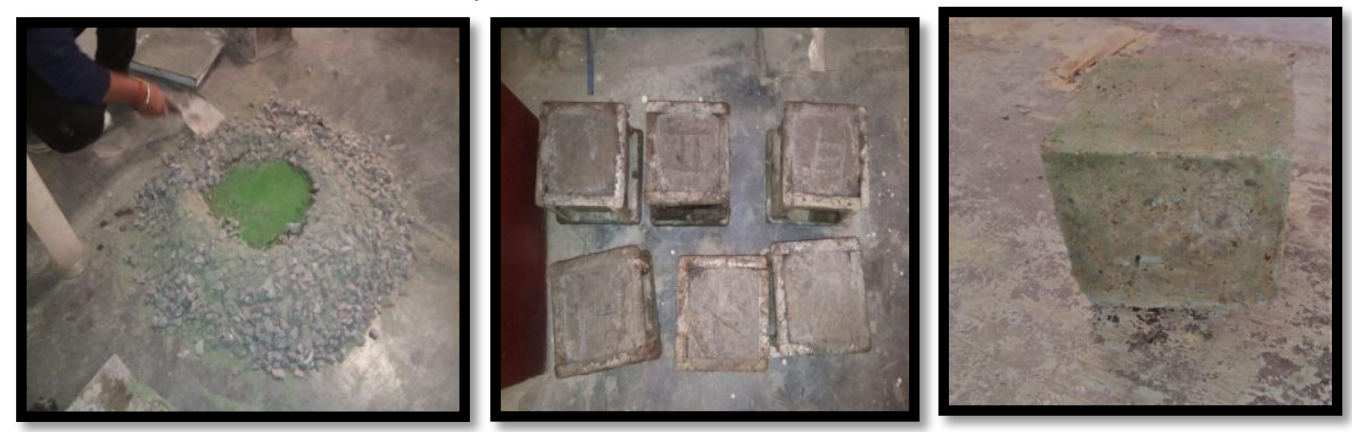

Figure 2: Steps of casting

\section{Result And Discussion}

\subsection{Test results of cement}

Table 1: Test results of cement

\begin{tabular}{|l|l|}
\hline Initial setting time & $100 \mathrm{~min}$. \\
\hline Final setting time & $220 \mathrm{~min}$. \\
\hline Consistency & $38 \%$ \\
\hline Compressive strength (28 days) & $47.57 \mathrm{Mpa}$ \\
\hline
\end{tabular}

\subsection{Test results of fine aggregate}

Table 2: Test results of fine aggregate

\begin{tabular}{|l|l|}
\hline Bulking of sand & $4.35 \%$ \\
\hline
\end{tabular}

\subsection{Test results of coarse aggregate}

Table 3: Test results of coarse aggregate

\begin{tabular}{|c|c|}
\hline Aggregate impact value & $12.12 \%$ \\
\hline Aggregate crushing value & $24.27 \%$ \\
\hline Aggregate abrasion value & $32.2 \%$ \\
\hline Aggregate water absorption & $0.295 \%$ \\
\hline
\end{tabular}

4.4. Compressive strength testing of concrete cubes $(.15 x .15 \times .15 \mathrm{~m})$

4.5.1. For $0 \%$ plastic waste replacement (conventional cube)

Table 4: Compressive strength for $0 \%$ replacement

\begin{tabular}{|c|c|c|c|c|c|}
\hline S.NO. & NO.OF DAYS & CUBE 1 & CUBE 2 & CUBE 3 & AVERAGE \\
\hline 1. & 7 DAYS & 24.0 & 28.0 & 26.0 & 26.0 \\
\hline 2. & 14 DAYS & 26.0 & 27.0 & 28.0 & 27.0 \\
\hline 3. & 28 DAYS & 32.88 & 33.33 & 31.33 & 32.51 \\
\hline
\end{tabular}

4.5.2. For $5 \%$ plastic waste replacement (along with $100 \mathrm{gm}$ of iron fibres in each cube) 
Table 5: Compressive strength for 5\% replacement

\begin{tabular}{|c|c|c|c|c|c|}
\hline S.NO. & NO.OF DAYS & CUBE 1 & CUBE 2 & CUBE 3 & AVERAGE \\
\hline 1. & 7 DAYS & 19.2 & 17.3 & 17.3 & 17.9 \\
\hline 2. & 14 DAYS & 22.66 & 22.66 & 23.55 & 23.03 \\
\hline 3. & 28 DAYS & 30.22 & 30.44 & 30.0 & 30.22 \\
\hline
\end{tabular}

4.5.3. For $10 \%$ plastic waste replacement (along with $100 \mathrm{gm}$ of iron fibres in each cube)

Table 6: Compressive strength for $10 \%$ replacement

\begin{tabular}{|c|c|c|c|c|c|}
\hline S.NO. & NO.OF DAYS & CUBE 1 & CUBE 2 & CUBE 3 & AVERAGE \\
\hline 1. & 7 DAYS & 16.88 & 18.66 & 17.55 & 17.7 \\
\hline 2. & 14 DAYS & 24.44 & 24.44 & 24.88 & 24.58 \\
\hline 3. & 28 DAYS & 26.66 & 26.88 & 28.0 & 27.18 \\
\hline
\end{tabular}

4.5.4. For $15 \%$ plastic waste replacement (along with $100 \mathrm{gm}$ of iron fibres in each cube)

Table 7: Compressive strength for $15 \%$ replacement

\begin{tabular}{|c|c|c|c|c|c|}
\hline S.NO. & NO.OF DAYS & CUBE 1 & CUBE 2 & CUBE 3 & AVERAGE \\
\hline 1. & 7 DAYS & 18.0 & 16.4 & 17.6 & $17.3 \mathrm{MPa}$ \\
\hline 2. & 14 DAYS & 22.4 & 23.5 & 25.2 & $23.7 \mathrm{MPa}$ \\
\hline 3. & 28 DAYS & 27.6 & 25.7 & 26.5 & $26.6 \mathrm{MPa}$ \\
\hline
\end{tabular}

4.5.5. For $20 \%$ plastic waste replacement (along with $100 \mathrm{gm}$ of iron fibres in each cube)

Table 8: Compressive strength for $20 \%$ replacement

\begin{tabular}{|c|c|c|c|c|c|}
\hline S.NO. & NO.OF DAYS & CUBE 1 & CUBE 2 & CUBE 3 & AVERAGE \\
\hline 1. & 7 DAYS & 11.77 & 12.44 & 11.11 & 11.77 \\
\hline 2. & 14 DAYS & 16.0 & 17.33 & 17.11 & 16.81 \\
\hline 3. & 28 DAYS & 24.0 & 23.77 & 24.0 & 23.92 \\
\hline
\end{tabular}

4.5.6. For $25 \%$ plastic waste replacement (along with $100 \mathrm{gm}$ of iron fibres in each cube)

Table 9: Compressive strength for $25 \%$ replacement

\begin{tabular}{|c|c|c|c|c|c|}
\hline S.NO. & NO.OF DAYS & CUBE 1 & CUBE 2 & CUBE 3 & AVERAGE \\
\hline 1. & 7 DAYS & 12.66 & 12.0 & 13.33 & 12.66 \\
\hline 2. & 14 DAYS & 17.78 & 17.78 & 17.11 & 17.55 \\
\hline 3. & 28 DAYS & 24.88 & 24.66 & 24.88 & 24.8 \\
\hline
\end{tabular}

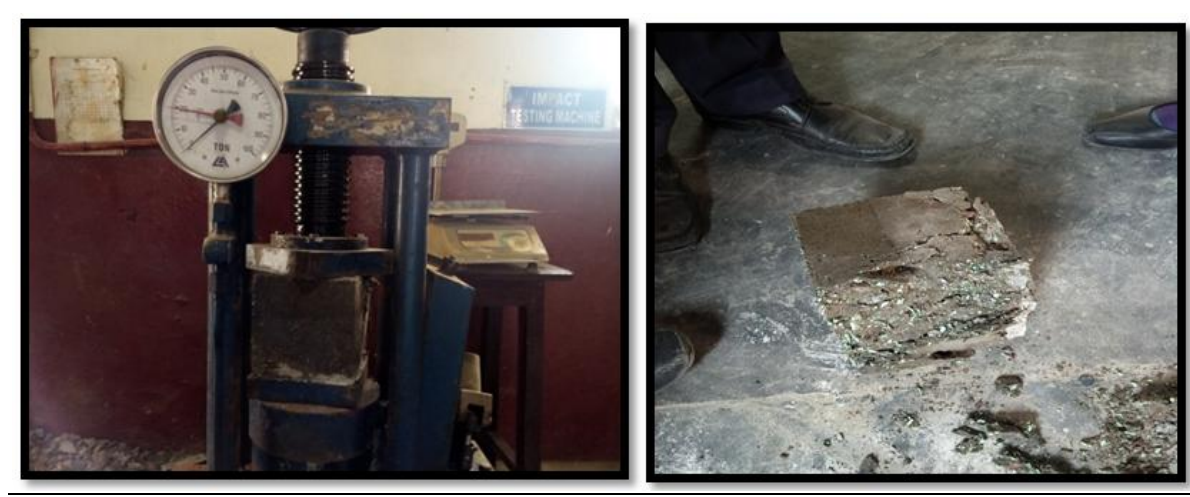

Figure 3: Compressive strength test of sample and cube after failure

\subsection{Comparative study}

The result obtained for different percentages of replacement of coarse sand by plastic is compared with the cube with $0 \%$ replacement (ideal M20 grade concrete cube) and the following graph is plotted.

The graph shows the variation of compressive strength with change in composition. 


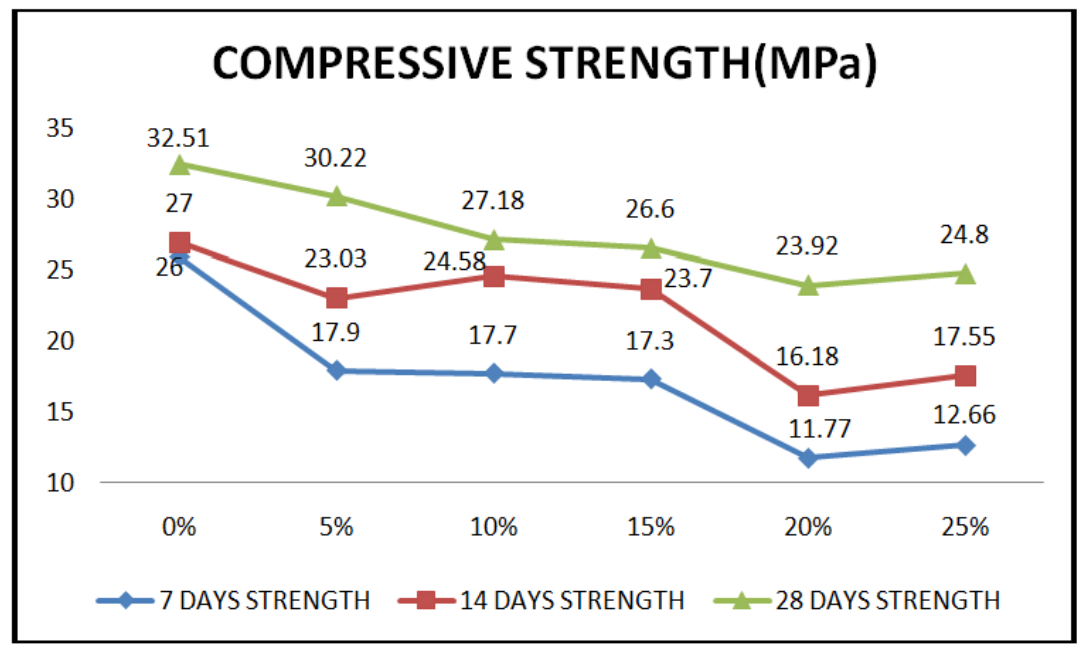

Figure 4: Compressive strength comparative study

\section{Conclusions}

1. The compressive strength of concrete keeps on decreasing as the percentage of plastic is increased in concrete as a replacement of fine aggregate.

2. A concrete mixture made of $25 \%$ plastic waste had lowest compressive strength at 28 days curing age that was $23.7 \%$ below the value of the conventional concrete mixture. The compressive strength reaches below $20 \mathrm{MPa}$ with further increase in plastic content.

3. There is very less effect on workability of concrete when fine aggregate is partially replaced by plastic.

4. Best compressive strength is obtained at 5\% fine aggregate replacement with plastic waste and using steel fibre reinforcement.

5. As the strength of $5 \%$ replaced concrete is very close to the conventional cube strength hence it can be concluded that it is safe to use plastic as partial replacement of fine aggregate $(5 \%)$ with $100 \mathrm{gm} /(0.15 \mathrm{~m})^{3}$ of iron fibres in concrete.

\section{References}

[1]. Hassani, A., Ganjidoust, H., Maghanaki, A.A., 2005, Use of plastic waste (poly-ethylene terephthalate) in asphalt concrete mixture as aggregate replacement. Waste Management \& Research 23, 322-327.

[2]. Indrajit Patel, C D Modhera, Study effect of polyester fibers on engineering properties of high volume fly ash concrete, Journal of Engineering Research and Studies.

[3]. IS 2386 (Part 5):1963 Methods of test for aggregates for concrete - Part 5 soundness.

[4]. IS 2386(Part 1):1963 Methods of test for aggregates for concrete- Part I particle size and shape.

[5]. IS 2386(Part 4):1963 Methods of test for aggregates for concrete: Part 4 mechanical properties.

[6]. IS 383:1970 - Specification for coarse and fine aggregates from Natural sources for concrete.

[7]. IS:4031(Part 4):1988-Methods of physical tests for hydraulic cement (Determination of consistency of standard cement paste).

[8]. Marzouk, O.Y., Dheilly, R.M., Queneudec, M., 2007,Valorization of post-consumer waste plastic in cementitious concrete composites, Waste Management 27, 310-318.

[9]. Rebeiz, K.S., Fowler, D.W., 1996. Flexural strength of reinforced polymer concrete made with recycled plastic waste. Structural Journal 93 (5), 524-530.

[10]. Soroushian, P., Mirza, F., Alhozaimy, A., 1995,Permeability characteristics of polypropylene fiber reinforced concrete,ACI Materials Journal 92 (3), 291-295. 